\title{
The Effects of Environment-conscious Consumer Attitudes towards Eco-friendly Product and Artificial Leather Fashion Product Purchase Intentions
}

\author{
Sung Hee Park ${ }^{1)}$, Kyung Wha $\mathrm{Oh}^{2) \dagger}$, and Youn Kyu $\mathrm{Na}^{1)}$ \\ ${ }^{1)}$ Dept. of Clothing \& Textiles, Chung-Ang University; Seoul, Korea \\ ${ }^{2)}$ Dept. of Home Economics Education, Chung-Ang University; Seoul, Korea
}

\begin{abstract}
This research examines the environmental consciousness of fashion consumer attitudes towards eco-friendly products and artificial leather purchase intentions. The survey was conducted from March 11 to March 152012 and all respondents had at least once experience of purchasing fashion items made of artificial leather. A total of 426 subjects were used in the dataset; the statistical analysis methods were frequency analysis, factor analysis, reliability analysis and multiple analysis. The results are as follows. The study finds that environmental consciousness has three dimensions of public participation, resource conservation, and recycling. Public participation, recycling, and resource conservation influenced eco-friendly product attitudes. Eco-friendly product attitudes influenced artificial leather purchase intentions. The research results show that appropriate plans in fashion business such as usefulness of design and business value will need to be provided to fashion consumers. Detailed information on materials related to fashion products as the content of environment-friendly techniques and recycling methods will help consumers to evaluate environmental-friendly attitude products.
\end{abstract}

Key words: environmental consciousness, eco-friendly product attitudes, consumer environmental concern, artificial leather fashion purchase intentions

\section{Introduction}

Pollution, climate changes, and natural disasters have changed $21^{\text {st }}$ century consumption tendencies towards eco-friendly attitudes; subsequently, many companies have made significant efforts towards the development of eco-friendly products and marketing strategies in order to find new opportunities. Increased consumer interest in environmental problems has changed consumer consciousness, lifestyles and behavioral patterns(Park \& Oh, 2005). Government and corporations seek to offer environmental solutions to the enforcement of environmental regulations. There are now stricter regulations and heightened consumer consciousness over the environment; subsequently, the importance of eco-friendly management of global corporations has increased.

Many countries have established eco-friendly development, manufacturing, and supply policies to meet the demands of global markets. For example, the OECD chose environmentally friendly government procurement policies through direct recommendation, and the US and Japan made it mandatory to purchase eco-friendly products and services through the Green Consumption Act(Korea Fashion Association, 2012).

†Corresponding author; Kyung Wha Oh

Tel. +82-2-820-5381, Fax. +82-2-826-4243

E-mail: kwhaoh@cau.ac.kr
Corporations wish to harness new economic growth trends based on the development of environmentally friendly fashion products and marketing methods for those products. Public awareness research on eco-friendly products by the Ministry of Environment and the Government Information Agency showed that $59.7 \%$ of Koreans are interested in such products and $73 \%$ of them wish to purchase them even if the price of these items is higher than regular prices. The results indicate that consumer eco-consciousness is increasing(Korea Development Institute, 2009).

The product preference which reflects consumer needs has grown with high-level sensibility as well as value consumption through product information. There is increased public interest in artificial leather fashion products as environmentally friendly and sustainable goods due to the desire to protect nature and animals. There are various kinds of fashion items included these markettendencies as shown through constant product development and new merchandising strategies. Corporations and consumers are especially interested in artificial leather fashion products as shown through ongoing eco-consciousness studies.

This study examined how eco-friendly consciousness and fashion consumer attitudes influence purchase intentions as well as investigated moderating effects between consciousness and purchase intentions. We examine consumer purchasing patterns and provide information on the establishment of new marketing strategies and the development of artificial leather fashion items. 


\section{Theoretical Background}

\subsection{Environment Conscious Attitude of Consumers}

It is important for consumers to evolve lifestyle and behavioral patterns in order to resolve environmental problems; subsequently, an increased consumer eco-consciousness results in a more positive towards eco-conscious activities(Lee, 2003). Eco-consciousness means that a consumer is more cognizant about environmental problems and follows a more environmentally friendly lifestyle that results inmitigated environmental problems in the purchase, use, or disposal of goods(Ahn \& Park, 1998). This reduction in waste also entails reduced energy consumption to help preserve the natural environment. These behavioral patterns produce positive results in the preservation of nature through a lifestyle that is harmonized with nature and are considered behavior that improves the quality of life in consumers(Min \& Rhee, 1999; Cha, 2000).

Eco-conscious behavior is an environmentally friendly consumption philosophy that recognizes the importance of the relationship between society and the environment as well as considers individual desires and the well-being of society as a whole. These behavioral patterns arise throughout the purchase of, use and disposal of goods(Park \& Rhee, 1995). Recycling is found to be closely related to pro-social behavior such as altruism and social contribution(Hopper \& Nielsen, 1991). A study by Park and $\mathrm{Oh}(2005)$ suggests eco-conscious behavior is categorized as resource conservation, public awareness, environmental preservation and recycling consciousness with significant effects on apparel recycling attitude and behavior. Park and Rhee(1995) argued that eco-conscious behavior was positively affected by the influence of reference groups, environmental interest, consumer efficiency, public awareness, income level, consumer awareness, and exposure to environmental education.

Kim(1995) studies on eco-conscious consumer behavior and clothing purchasing type showed that there were purchase behavior differences between high eco-consciousness and low eco-consciousness groups and that the high eco-consciousness group was more active in recycling clothes. A study by Shim(1995) on recycling tendencies in the case of clothes disposal found that females recycled more clothing than males. Continuous research and study on eco-conscious behavior helps to understand consumer behavior and emphasizes it as the most important artificial leather fashion item purchasing behavior variable; therefore, previous studies searched for eco-conscious behavior, resource conservation, and recycling consciousness.

\subsection{Attitude on Environmentally Friendly Products}

An environmentally friendly product attitude occurs when con- sumers assume an environmentally friendly position in their individual and social lives. The ultimate purpose of purchasing is for consumers to satisfy their wants and needs. In this context, an environmentally friendly product attitude results in the purchase of environmentally friendly goods(Sung, 2005). It is also a belief that people maintain constructive thoughts towards environmental problems and preservation(Lee, 1999). The environmental attitude of consumers is a collective concept that embraces all consumer awareness towards environmental problems as expressed in terms such as environmental consciousness, environmental interest and environment preservation attitude(Won, 2003; Park, 2012).

Studies on attitudes towards environmentally friendly products have mainly focused on the characteristics of eco-friendly consumers(Lee et al., 2002; Park \& Lee, 1995) and eco-friendly consumers are defined as those who conduct purchasing activities based on a consideration of the benefits provided to society and the environment. Consumers have significant interest in environmental problems and eco-friendly consumers have begun to emerge as a new consumer group in the market. Environmentally friendly consumers are sensitive towards and consider environmental effects when they purchase products; in addition, they alter purchasing and using patterns based upon environmental preservation(Hong et al., 2010). Advanced research on eco-friendly customer attitudes compares the differences of environmentally friendly consumers and non-environmentally friendly consumers based on population statistical variables and eco-friendly variables(Yun \& Yang, 2009). Individual personality shows more environmental interest than the socioeconomic factors found in the research by Park and Suh(1998).

Individual personality emphasizes segmented customer character variables as well as demographic characteristics to show that they would positively and consciously participate in environmentoriented behavior, education, and practices towards the environment.

Research by Balderjahn(1988) shows that customers who have an increased interest and positive attitude towards the environment become personally active in their involvement energy conservation and eco-friendly purchasing. Jung(2009) also analyzed the purchasing activity of environmentally-friendly fashion that followed environmentally-friendly attitudes and segmented attitudes into an interest in environmental friendly attitudes, environmental activity participation level and the level of environmental friendly product consumption. Min and Rhee(1999) examined environmentally friendly consumption attitudes at the social-oriented level and individual-oriented level; they claimed that direct individual benefits are more influential than social concerns to promote the activity. He showed that there were more cases of consumer expression in their 
initial behavior when they respond sensitively to direct environmental damages or benefits. Huh(2004) categorized the purchasing activities of consumers to examine if there were any differences between the environment and environmentally friendly behavior; however, Park(2000) stated that environmental interest and attitude contained the influential variables of eco-friendly consumer behavior. Salient research on environmentally friendly product shows the importance of environmental awareness behavior.

\subsection{Consumer Interest in the Environment}

Consumer interest in the environment is determined through the consumer attitude towards environmental issues such as pollution, population growth, sustainable growth and natural resource development(Liere \& Dunlap, 1981). Research to develop environmental interest criterion for environmental problems has progressed; however, Stern et al.(1993) states the need for a varied analysis to understand the main causes and solutions to environmental destruction. He argues for a research method to evaluate individual feelings and convictions towards the environment needs; in addition, he clarified the factors needed to protect the environment and developed criterion for environmental preservation.

Schwepker and Cornwell(1991) conducted research on changes of attitudeby environmental-friendly consumers to clarify the importance of environmental issues through a practical research on the environment. They also inquired on the practical factors that influence environmental issues with further research on the seriousness and degree of concern towards the changes of attitude by consumer groups.

We have to consider attitude and behavior in the evaluation of the degree of environmental concern. Social psychology emphasizes the relation of environmental attitudes and environmental behavior where behavior becomes a more important issue than the attitude(Liere \& Dunlap, 1981). New research on consumers with substantial environmental interest involves conscious environmental-friendly activities as well as shifts in perceptions towards an evaluation of environmental policy and the will to resolve environmental issues. Environmental seriousness and interest are theemotional and rational preferences of individuals when individual preference becomes the basis for eco-awareness. Consumers interested in the environment have a detailed and professional knowledge towards the environment and are classified as highly responsible consumers based on environmental-friendly consumption(Park, 2000).

There is a significant correlation between consumer interest in the environment and super behavior related to the environment due to the close correlation of environmental-friendly attitudes and purchasing behavior in the criterion related to the environmental inter- est of the consumer(Stern et al., 1993). The research of Rice et al. (1997) recognized the relevance of environmental interest and consumption behavior in an environmental conscious manner. Previous studies show and eco-friendly attitude and environmentally conscious purchasing behavior correlation; in addition, an ecofriendly attitude significantly influenced artificial leather fashionproduct purchase intentions.

\subsection{Artificial leather fashion product purchasing intentions}

Purchasing behavior is related to product and brand evaluation as well as behavior related to selection and intention(Noh, 1996). The data processing theory shows that consumers form attitudes by conviction based on the attributes of a product as proven by a continued purchasing behavior. Consumers can go through three steps such as perception, attitude and behavior intention when they obtain and ultimate purchase behavior level. Lee(2008) defined purchasing intention as expected or planned future behavior or the possibility of changing behavior attitudes.

Research on environmental-friendly product purchasing activities verified crucial variables that influence environmental-friendly product purchasing behavior(Jeong \& Park, 2006). Alwitt and Pitts(1996) emphasized the importance of environmental-friendly consumer purchasing behavior as they clarified that environmental interest influence environment related product purchasing intentions.

Research by Schwepker and Cornwell(1991) clarified that environmental-friendly attitudes are an important purchasing intention variable through the perception on attitudes towards waste materials and environmental pollution.

Koh and Noh(2009) claimed that ethical consumption statistically influence attitudes towards ethical fashion product purchases and purchase intentions. Kim(2004) show that environmental purchasing behavior can be considered a simple purchasing behavior(buying used products, utilizing resource-saving products, and selecting environmental products) as well as an environmental conscious behavior throughout the whole product purchasing process. Research shows an active environmental-friendly purchasing behavior; however, research on artificial leather fashion products is limited and in need of further investigation.

\section{Method}

\subsection{Research Problems and Research Model}

The following research problems were implemented to understand the environmental-conscious behavior of consumers and the relationship of eco-friendly product attitudes and artificial leather fashion product purchasing intentions. 
- Research Problem 1

Quantify consumer behavior towards environmental concepts.

- Research Problem 2

Understand the effects of environmentally conscious consumer behavior on eco-friendly product attitudes.

- Research Problem 3

Examine the effects of consumer attitude towards environmental-friendly products and artificial leather fashion product purchasing intentions.

\section{- Research Problem 4}

Study the controlling effect of consumer's environmental interest on the relationship between environment-friendly product attitudes and artificial leather fashion product purchase intentions.

\subsection{Measurement Tools}

A questionnaire was used for the practical survey and a survey was conducted on consumers who had at least one artificial leather fashion product purchase experience. The content of the questionnaire consisted of questions related to environmental behavior, environmental-friendly product attitudes, artificial leather fashion product purchasing intentions, and environmental interest. Environmental-friendly behavior content were based on research and preliminary surveys by Park and Oh(2005), Kim(2004), and Hop- per and Nielsen(1991), which were measured in 20 questions on 5 point Likert criterion. There were 8 questions based on environmental-friendly product attitude research by Won(2003) and Jung(2009); in addition, there were 5 questions( 5 points each) for the environmental interest of consumers by Cho and Kim(2003) and Rice et al.(1997). Statistical population characteristics such as gender, age, marital status, school, and occupation were measured on a nominal scale.

\subsection{Data Collection and Analysis}

A question survey collected data on consumers over 20 years of age who had artificial leather fashion product purchasing experiences. A preliminary survey asked 100 people from February $10^{\text {th }}$ to $22^{\text {nd }} 2012$ and then ambiguous questions were modified to answer easily through the preliminary survey.

This research implemented an internet questionnaire from March $1^{\text {st }}$ to $15^{\text {th }} 2012$ that provided a data sample of 426 responses. An SPSS 19.0 program conducted the frequency analysis of credibility, factors, and multiple regression of collected data. Men and women were divided by gender to account for population statistical characteristics of the research target data and consisted of 213 people each(50\%). For age, there were 100 people in 20 s(23.5\%), 105 people in $30 \mathrm{~s}(24.6 \%), 111$ people in $40 \mathrm{~s}(26.1 \%)$, and 110 people in

Table 1. Factor analysis of consciousness of environmental fashion consumers

\begin{tabular}{|c|c|c|c|c|c|}
\hline Factor & Items & $\begin{array}{l}\text { Factor } \\
\text { Loading }\end{array}$ & $\begin{array}{l}\text { Eigen } \\
\text { Value }\end{array}$ & $\begin{array}{l}\text { Variance } \\
\%\end{array}$ & Cronbach's $\alpha$ \\
\hline \multirow{5}{*}{$\begin{array}{l}\text { Civic activist } \\
\text { participation }\end{array}$} & $\begin{array}{l}\text { The problem of air pollution is something that the government and corporations should take } \\
\text { care of; however, I also have to be interested in it and try to solve it. }\end{array}$ & .770 & \multirow{5}{*}{4.382} & \multirow{5}{*}{23.07} & \multirow{5}{*}{.80} \\
\hline & It would be helpful for environmental conservation of Korea if the matter is resolved privately. & .768 & & & \\
\hline & I believe the environmental pollution problem is serious. & .675 & & & \\
\hline & $\begin{array}{l}\text { The development of eco-friendly products by companies has to be done } \\
\text { (through government regulations). }\end{array}$ & .660 & & & \\
\hline & $\begin{array}{l}\text { I am interested in attending consumer environmental issue education classes held by } \\
\text { schools, social communities or companies. }\end{array}$ & .605 & & & \\
\hline \multirow{6}{*}{$\begin{array}{l}\text { Conservation } \\
\text { consciousness }\end{array}$} & I usually use recyclable shopping bags when shopping. & .707 & \multirow{6}{*}{3.392} & \multirow{6}{*}{40.91} & \multirow{6}{*}{.81} \\
\hline & I have purchased recycled plastic, bottle or can products. & .674 & & & \\
\hline & I am conscious of using water for personal hygiene in order to save water. & .669 & & & \\
\hline & $\begin{array}{l}\text { I walk or use public transportation when going the nearby places to save energy and } \\
\text { protect the environment. }\end{array}$ & .651 & & & \\
\hline & I sort my recyclable garbage. & .606 & & & \\
\hline & I try not to use the disposable products. & .598 & & & \\
\hline \multirow{6}{*}{$\begin{array}{l}\text { Recycling } \\
\text { consciousness }\end{array}$} & I am very interested in environmental issues. & .669 & \multirow{6}{*}{3.201} & \multirow{6}{*}{60.13} & \multirow{6}{*}{.79} \\
\hline & I am very interested in environmental management by companies or green marketing. & .631 & & & \\
\hline & I have an experience in purchasing recycled products at recycling shops or second-hand stores. & .620 & & & \\
\hline & $\begin{array}{l}\text { I believe it is better to use products that are environmentally less harmful, even though } \\
\text { the price is a bit higher. }\end{array}$ & .605 & & & \\
\hline & I am willing to endure inconvenience to solve environmental problems. & .590 & & & \\
\hline & I am currently more interested in the environmental issues compared to 10 years ago. & .580 & & & \\
\hline
\end{tabular}


50s $(25.8 \%)$. As for marital status, there were 291 people mar$\operatorname{ried}(68.3 \%)$ and 135 people single(31.7\%). Education consisted of 122(28.9\%) high school graduates, 56(13.1\%) junior college graduates, $213(50 \%)$ university graduates, and $34(8.0 \%)$ graduate school students. Occupation was broken down into $119(27.9 \%)$ businessmen, $77(18.1 \%)$ technicians, and 78 housewives(18.3\%).

\section{Results and Discussion}

\subsection{Factor Analysis and Credibility Analysis}

\subsubsection{Environmental Conscious Behavior by Consumers}

A factor analysis measured the validity of composition concepts through a main Varimax circulation analysis of angle spinning with Kaiser normalization. A factor loading figure over 0.5 and larger than 1.0 standard in the process of factor extraction was considered as an effective variable; therefore, the items with effective costs were extracted to be factorized after the factor circulation. Table 1 shows the results of the environmental conscious behavior factor analysis of consumers. Factor 1 consisted of questions called "Citizen's Activity and Sense of Participation" about education participation in environmental problems such as pollution problems, environmental pollution, and environmental problems at school, society organization, and enterprises. Factor 2 consisted of questions called "Sense of Resource Savings" that inquired about shopping baskets when shopping, conserving water, and using masstransportation to save energy. Factor 3 consisted of contents called
"Sense of Recycling" that examined interest in environmental issues, recycled products, and products that are not environmentally toxic to the environment(even if more expensive). Factor 2, "Citizen's Activity and Sense of Participation"(which the factor cost is below 0.5) and Factor 1 "Sense of Recycling" were removed. The total variable was $60.13 \%$ and the coefficient of confidence was more than $0.7 \%$. Environmentally conscious behavior was classified into resource saving consciousness, participation consciousness, environment preservation, and recycling consciousness in the research related to the effect of materialistic tendency, environmental conscious attitude and behavior as analyzed by Park and $\mathrm{Oh}(2005)$. This research showed that a sense of resource savings and sense of recycling were partially consistent.

4.1.2. Eco-friendly product attitude of Consumers, Artificial leather fashion product purchasing intentions, and Environmental Consumer Interest

Table 2 shows the factor analysis results of fashion consumer eco-friendly product attitudes divided into artificial leather fashion product purchasing intentions and the environmental interest of consumers. Environmentally friendly product attitudes consisted of 7 questions and had a factor loading figure under 0.5. The total variable about this factor was $61.26 \%$ and the confidence coefficient was over 0.8 . The artificial leather fashion product purchasing intention consisted of 5 questions with a total variable of $64.69 \%$ and a confidence of coefficient over 0.8 .

Table 2. Factor analysis of attitude on Eco-friendly products, artificial leather fashion product purchase intentions, and consumer environmental concern.

\begin{tabular}{|c|c|c|c|c|c|}
\hline Factor & Items & $\begin{array}{l}\text { Factor } \\
\text { Loading }\end{array}$ & $\begin{array}{l}\text { Eigen } \\
\text { Value }\end{array}$ & $\begin{array}{l}\text { Variance } \\
\quad \%\end{array}$ & Cronbach's $\alpha$ \\
\hline \multirow{7}{*}{$\begin{array}{l}\text { Eco-friendly } \\
\text { product attitude }\end{array}$} & I feel more inclined towards eco-friendly fashion items than to normal items. & .84 & \multirow{7}{*}{4.30} & \multirow{7}{*}{61.26} & \multirow{7}{*}{0.81} \\
\hline & I feel eco-friendly fashion items are more friendly than normal items. & .80 & & & \\
\hline & The eco-friendly fashion items are more attractive than the normal items. & .79 & & & \\
\hline & The eco-friendly fashion items are more trustful than the normal items. & .79 & & & \\
\hline & I am interested in fashion items made of eco-friendly materials. & .77 & & & \\
\hline & I am interested in eco-friendly fashion. & .77 & & & \\
\hline & I intend to purchase eco-friendly items even if they are more expensive. & .70 & & & \\
\hline \multirow{4}{*}{$\begin{array}{l}\text { Artificial leather } \\
\text { purchase } \\
\text { intentions }\end{array}$} & I intend to purchase eco-friendly artificial leather and not purchase real leather. & .83 & \multirow{4}{*}{2.59} & \multirow{4}{*}{64.69} & \multirow{4}{*}{0.80} \\
\hline & $\begin{array}{l}\text { I intend to purchase eco-friendly artificial leather to protect animals and the } \\
\text { environment. }\end{array}$ & .82 & & & \\
\hline & I intend to purchase eco-friendly artificial leather even though it is expensive. & .80 & & & \\
\hline & $\begin{array}{l}\text { I intend to purchase eco-friendly artificial leather even though the quality, form } \\
\text { and touch are inferior. }\end{array}$ & .77 & & & \\
\hline \multirow{5}{*}{$\begin{array}{l}\text { Consumer } \\
\text { environmental } \\
\text { concern }\end{array}$} & I usually donate to community chest drive TV programs. & .82 & \multirow{5}{*}{4.11} & \multirow{5}{*}{62.51} & \multirow{5}{*}{0.80} \\
\hline & I use both sides of the paper. & .80 & & & \\
\hline & I take great care of my health though I am busy. & .80 & & & \\
\hline & I usually use recyclable shopping bags or shopping baskets when shopping. & .78 & & & \\
\hline & I manage my expenses by keeping receipts and a household account. & .78 & & & \\
\hline
\end{tabular}


Table 3. Effect of Eco-friendly products and consumer environment on environmental fashion consumer consciousness

\begin{tabular}{clcccc}
\hline Dependent variance & \multicolumn{1}{c}{ Independent variance } & $\beta$ & $\mathrm{t}$ & $\mathrm{F}$ & $\mathrm{R}^{2}$ \\
\hline \multirow{3}{*}{ Eco-friendly productattitudes } & Civic activist Participation Consciousness & .188 & $5.018^{* * *}$ & & \multirow{2}{*}{.406} \\
& Conservation Consciousness & .191 & $5.096^{* * *}$ & $96.045^{* * *}$ & .406 \\
& Recycling consciousness & .578 & $15.394^{* * *}$ & & \\
\hline
\end{tabular}

***p<.001

The environment interest of consumers consisted of 5 questions and the total variable was $64.69 \%$; in addition, the confidence of coefficient was also high.

\subsection{The effect of environmentally conscious consumer behavior attitudes towards eco-friendly products}

The sense of activity, participation, saving resources, and recyclingof citizens were designated as independent variables in order to understand the environmental conscious behavior effect of consumer attitudes on eco-friendly products. Environmental product attitudes were asubordinate variable in the multiple regression analysis; subsequently, Table 3 shows that citizen's sense of activity, participation, saving resources, and recycling were important environmental product attitude factors. The sense of participation and citizen's environmental-friendly product attitudes showed $\beta=0.188$ $\mathrm{t}=5.018, \mathrm{p}<.001$, conservation showed $\beta=0.1915 \mathrm{t}=5.096, \mathrm{p}<.001$, and sense of recycling showed $\beta=0.578 \mathrm{t}=15.394, \mathrm{p}<.001$, which were statistically significant and the total explanation ability was $40.6 \%$. The recycling conscious regression value was higher because consumers with more environmental interest and recycling activities were more amicable towards environment-friendly products. Research related to environmental-friendly fashion product purchasing activities followed the hypothesis of Jung(2009); subsequently, resource saving was the most important factor and seems to partially correlate with previous studies.

\subsection{Effects of Environment-Friendly Product on Artificial Letter Fashion Product Purchase Intentions}

We conducted an analysis of multiple regression with environmental-friendly attitude as an independent variable and fashion product purchasing intentions as a subordinate variable in order to understand the environmental product attitude effect on fashion product purchasing intentions. Subsequently, all attitude factors on environment-friendly products had a significant effect on artificial leather fashion product purchasing intentions. The environmentfriendly products attitudes influenced at $\beta=0.655, t=18.230 \mathrm{p}<.001$ and the total explanation ability was $45.8 \%$. This research on environmentally consciousness purchasing behavior leads to be thesignificant effect with environmental product purchase intentions and correlates with $\operatorname{Kim}(2004)$.
Table 4. The effect of artificial leather purchase intention attitudes on Eco-friendly products

\begin{tabular}{cccccc}
\hline $\begin{array}{c}\text { Dependent } \\
\text { variance }\end{array}$ & $\begin{array}{c}\text { Independent } \\
\text { variance }\end{array}$ & $\beta$ & $\mathrm{t}$ & $\mathrm{F}$ & $\mathrm{R}^{2}$ \\
\hline $\begin{array}{c}\text { Artificial leather } \\
\text { purchase intentions productattitudes }\end{array}$ & $\begin{array}{c}\text { Eco-friendly } \\
\text { Ex* }\end{array}$ & & $18.230 * * * *$ & $178.722 * * *$ & .458 \\
\hline$* 0<.001$
\end{tabular}

Table 5. Moderating effects of consumer environmental consciousness

\begin{tabular}{cccccc}
\hline $\begin{array}{c}\text { Dependent } \\
\text { variance }\end{array}$ & $\begin{array}{c}\text { Independent } \\
\text { variance }\end{array}$ & $\begin{array}{c}\text { Moderating } \\
\text { variance }\end{array}$ & $* \mathrm{R}^{2}$ & $* * \mathrm{R}^{2}$ & $\Delta \mathrm{R}^{2}$ \\
\hline $\begin{array}{c}\text { Artificial } \\
\text { leather } \\
\text { purchase } \\
\text { intentions }\end{array}$ & $\begin{array}{c}\text { Eco-friendly } \\
\text { product } \\
\text { attitudes }\end{array}$ & $\begin{array}{c}\text { Consumer } \\
\text { environmental } \\
\text { consciousness }\end{array}$ & .416 & .429 & $.000^{* * *}$ \\
$* * * p<.001$ & & & & \\
$* \mathrm{R}^{2}: \mathrm{R}^{2}$ of regression equation not included interaction term & \\
$* * \mathrm{R}^{2}: \mathrm{R}^{2}$ of regression equation included interaction term &
\end{tabular}

\subsection{Controlling Effect on Consumer's Environmental Interest}

The environmental interest of consumers analyzed the control regression to understand the control effect of environmentalfriendly product attitudes and artificial leather fashion product purchasing intentions; subsequently, the regression equation(as in Table 5) was statistically significant in the standard of $p<.001$. The explanation ability of the regression model between environmentfriendly product attitudes and artificial leather fashion product purchasing intentions was $41.6 \%$. However, there was a changed amount by $1.3 \%$ and showed the control effects in the control level of consumer's environmental interest with an explanation ability of $42.9 \%$. Larger numbers of consumers with an environmental interest results in higher artificial leather fashion product purchasing intentions.

\section{Conclusion}

This research analyzed the effects of consumer environmental consciousness behavior and eco-friendly attitude on the influential relationship of artificial leather fashion product purchase intentions, through consumers who have purchased leather products to provide basic marking strategy data for the leather fashion market. First, environmental consciousness behavior by consumers was 
classified into citizen's activity, participation, conservation, and recycling; however, the attitude on environment-friendly products and environmental interest by consumers appeared as single factors. Second, the effects of the environmental consciousness behavior by consumers influenced the environmental-friendly product attitudes. All environmental consciousness behavior factors significantly influenced attitudes. Third, the control effects of environmental interest on environmental product attitudes by consumers influenced leather product purchasing intentions and the environmental interest by customers showed the control effect of purchasing intentions.

The results of this study suggest a significance and implication of research. First, the behavior of environmental consciousness by consumers is classified into citizens' activity, participation, conservation, and recycling. All environmental consciousness behavior factors were important factors towards environmental-friendly product attitudes. The research results show that appropriate plans in fashion business such as usefulness of design and business value(not by pursuit of trends) will need to be provided to fashion consumers. Detailed information on materials related to fashion products(including clothing, shoes, bags, and accessories) as the content of environment-friendly techniques and recycling methods will help consumers to evaluate environmental-friendly attitude products. Second, environmental-friendly attitude products influenced artificial leather product purchasing intentions. There is increased and more varied research on artificial leather. Artificial leather is unlike the traditional life cycle of discarding products from raw materials; there is an interest in the behavior on the natural environment that differentiates existing artificial leathers. It would be useful to utilize ascientific method to simplify the consumers purchase of environmental-friendly products along with the continuous development of artificial leathers. Important factors that influence the environment and consumption at each level of the life cycle of fashion products need to be clarified and it will be useful to suggest methods to resolve environmental issues. Consumer information on the manufacturing process of artificial leathers will help clarify leather product purchasing intentions if a more prevalent environmental protection message is suggested along with more information on the advantages of artificial leather. Third, the environmental consumers interest variable shows the moderating effect between environment-friendly product attitudes and artificial leather fashion product purchasing intentions. Consumers with increased environmental interest were more positive with increased artificial leather product purchases. Artificial leather products should be considered a strategic factor for environment-friendly marketing as well as marketing factors(design, price, and quality) to increase environmentally conscious consumer purchases.
The practical survey in this research was limited to men and women aged from 20 to 50 and it would be difficult to extend the meaning to other classes of consumers. The results can differ dependingon age, gender, and occupation, behavior on environmental consciousness and attitude on environment-friendly; subsequently, further research that considers all these issues is imperative. Artificial leather as well as future fashion product development research on artificial fur and environment-friendly fibers are suggested as other areas of research.

\section{Acknowledgement}

This work was supported by the National Research Foundation of Korea(NRF) grant funded by the Korea government (MEST) (No. 2012047656).

\section{References}

Ahn, S. C., \& Park, S. Y. (1998). A study of consumer's environmental consciousness and purchasing behavior of environmental goods. Journal of Resource Development, 18(1), 14-25.

Alwitt, L. F., \& Pitts, R. E. (1996). Predicting purchase intentions for an environmentally sensitive product. Journal of Consumer Psychology, $5(1), 49-64$

Balderjahn, I. (1988). Personality variables and environmental attitudes as predictors of ecologically responsible consumption patterns. Journal of Business Research, 17(1), 51-56.

Cha, J. Y. (2000). Study on the relationship between pro-environmental consumption consciousness and behavior of teenager consumer. Unpublished master's thesis, Sookmyung University, Seoul.

Cho, Y. Y., \& Kim, K. H. (2003). Environmental consciousness in Korea. Korean Resource Economics Association, 21(1), 177-204.

Hong, B. S., Lee, E. J., \& Chu, Y. J. (2010). The effect of environmental values of fashion consumers on purchase satisfaction and repurchase intention of eco-friendly fashion products. Journal of the Korean Society for Clothing Industry, 12(4), 431-438.

Hopper, J. R., \& Nielsen, M. J. (1991). Recycling as altruistic behavior: normative and behavioral strategies to expand participation in a community recycling program. Environment and Behavior, 26(1), 195-220.

Huh, K. O. (2004). The effect of consumers' environmental conservation behavior on the purchase of pro-environmental and used products. International Journal of Human Ecology, 42(9), 85-97.

Jeong, Y. J., \& Park, O. L. (2006). A study on university student's clothing disposition behavior depending on their personality and environmental consciousness. Korean Journal of Human Ecology, 15(1), 157-164.

Jung, H. J. (2009). Extraction of evaluation criterion descriptions for public designs. Unpublished master's thesis, Chosun University, Gwangju.

Kim, Y. S. (2004). A model of the antecedents of consumers' green purchase behavior. Korean Journal of Marketing, 8(2), 1-26.

Kim, Y. D. (1995). Environmental consciousness \& clothing consump- 
tion behavior of the consumers. Unpublished master's thesis, Chung-Ang University, Seoul.

Koh, A. R., \& Noh, J. Y. (2009). Ethical fashion consumer behavior in Korea: factors influencing ethical fashion consumption. Journal of the Korean Society of Clothing and Textiles, 33(12), 1956-1964.

Korea Fashion Association. (2012). Fashion CEO report, pp. 20-28.

Korea Development Institute. (2009). Global environment forum 2009, pp. 3-7.

Lee, Y. J. (2008). Influences of globalization factors of Korean food on country image, attitudes and product buying intention. Unpublished master's thesis, KyungHee University, Seoul.

Lee, K. H. (1999). The relationships of clothing benefit and clothing attributes evaluation to ego identity of college students. The Research Journal of the Costume Culture, 7(4), 637-652.

Lee, C. H., Noh, J. K., \& Kim, Y. S. (2000). A study on the factors that influence the environmentally concerned consumption behavior. Business Administration, 29(2), 171-195.

Lee, S. H. (2003). A study on environment-friendly family resource management behaviors, environmental consciousness, knowledge, and education. Korea Home Management Association, 21(1), 91102

Lee, J. E., Kim, I., \& Park, S. K. (2002). A study on the consumer behavior on environmentally beneficial clothing. Journal of Fashion Business, 6(2), 77-92.

Min, H. S., \& Rhee, K. C. (1999). Consumers' pro-environmental attitude and behavior. International Journal of Human Ecology, $37(1), 29-44$.

Noh, J. K. (1996). A study on the relations between environmentally concerned consumption behavior and life style. Journal of Marketing Management, 2(1), 1-18

Park, K. Y. (2000). A theoretical study on the behaviors of the environmentally concerned consumer. Kyongiu University Research, 13(1), 295-309.

Park, H. H., \& Oh, S. D. (2005). The influence of materialism and environment consciousness on recycling attitude and behavior of clothing. Journal of the Korean Home Economics Association, 43(10), 167-177.

Park, U. A., \& Rhee, K. C. (1995). A study on environmentally conscious consumer behavior. International Journal of Human Ecology, 33(4),
$199-212$

Park, W. A., \& Lee, K. C. (1995). A study on environmentally conscious consumer behavior. Korean Home Management Association, 33(4), 199-210.

Park, H. S., \& Suh, Y. S. (1998). Environmental perception of consumers and clothing consumption behavior. Korean Home Management Association, 128, 79-88.

Park, Y. H. (2012). A study on the purchase appraisal standard and postpurchase satisfaction of natural dyeing products. Journal of the Korean Society for Clothing Industry, 14(1), 64-74.

Sung, Y. Y. (2005). A study on the environmental consciousness and behavior of the consumers in Incheon Area. Korean Home Management Association, 23(3), 35-51.

Rice, J., Farquhar, A., Piernot, P., \& Gruber, T. (1996). Using the web instead of a window System. Proceedings of ACM CHI 96 Conference on Human Factors in Computing Systems, Vancouver, $B C$, pp.103-110.

Stern, P. C., Dietz, T., \& Kalof, L. (1993). Value orientations, gender, and environmental concern. Environment and Behavior, 25(3), 322-348.

Shim, S. (1995). Environmentalism and consumers clothing disposal patterns: an exploratory study. Clothing and Textiles Research Journal, 13(1), 38-48.

Schwepker, C. H., \& Cornwell, T. B. (1991). An examination of ecologically concerned consumers and their intention to purchase ecologically packaged products. Journal of Public Policy and Marketing, 10(2), 77-101.

Van Liere, K. D., \& Dunlap, R. E. (1981). Environment concern does make a difference how it'smeasured. Environment and Behavior, 13(6), 651-676.

Won, D. D. (2003). Study on the relationship between pro-environmental consumption consciousness and behavior of teenager consumer. Unpublished doctoral dissertation, Wonkwang University, Iksan.

Yun, S. W., \& Yang, Y. J. (2009). Analysis of the difference in environment-friendly behavior based on list of value. Marketing Management Research, 14(2), 103-122.

(Received 3 August 2012; 1st Revised 8 September 2012; Accepted 27 December 2012)

Copyright $(\subset$ The Society of Fashion and Textile Industry. 2013. This is an open access article distributed under the terms and conditions of the Creative Commons Attribution Non-Commercial license (http://creativecommons.org/licenses/by-nc/3.0/), which permits unrestricted non-commercial use, distribution, and reproduction in any medium, provided the original work is properly cited. 